\title{
Synthesis and antifungal activity of $N$-aryl- $N$-benzylamines and of their homoallyl analogues
}

Francisco M. Garibotto, ${ }^{\text {a,b }}$ Maximiliano A. Sortino, ${ }^{\text {a,c }}$ Vladimir V. Kouznetsov, ${ }^{\text {d }}$ Ricardo D. Enriz, ${ }^{b, c}$ and Susana A. Zacchino ${ }^{a} *$

${ }^{a}$ Farmacognosia, Facultad de Ciencias Bioquímicas y Farmacéuticas, Universidad Nacional de Rosario. Suipacha 531, 2000-Rosario, Argentina

${ }^{b}$ Química General, Facultad de Química, Bioquímica y Farmacia, Universidad Nacional de San Luis, Chacabuco 915, 5700-San Luis, Argentina

${ }^{c}$ IMIBIO-CONICET, Universidad Nacional de San Luis, Chacabuco 915, 5700-San Luis, Argentina

${ }^{d}$ Laboratorio de Química Orgánica y Biomolecular, Escuela de Química, Universidad Industrial de Santander, A.A. 678 Bucaramanga, Colombia E-mail:szaabgil@citynet.net.ar

\section{In honour of Professors Rita H. Rossi, Julio C. Podestá, Manuel González Sierra and Oscar S. Giordano, recognising their contributions to the development of Organic Chemistry in Argentina}

\begin{abstract}
Ten $N$-aryl- $N$-benzylamines were synthesized and evaluated for their antifungal activity, which was compared with their homoallylamine analogues that possessed an allyl group in the carbon next to the nitrogen atom. Results indicated that the absence of the allyl group caused an enhancement of the antifungal activity which could be correlated with the flexibility of the alkyl chain between both aromatic groups. DFT calculations supported these differences in activity.
\end{abstract}

Keywords: $N$-arylamines, Homoallylamines, Antifungal, DFT calculations

\section{Introduction}

Among the different microbes that affect the quality of life, fungi have an enormous impact on morbidity and mortality, especially among the immunocompromised hosts, since they have emerged over the past two decades as major causes of human infections. ${ }^{1}$ They produce serious invasive mycoses in individuals submitted to organ transplantations or antineoplasic chemotherapy, those suffering the acquired immunodeficiency syndrome (AIDS), extremely 
aged persons and patients in intensive care units, among others. ${ }^{2,3}$ They also produce superficial fungal infections (those involving the skin and mucosal surfaces) not only in immunocompromised hosts but in healthy individuals, including children of third-world nations that receive deficient sanitary attention and education, highly diminishing the quality of their lives. ${ }^{4,5}$

Although there appears to be a big armamentarium of antifungal drugs in clinical use, in fact only a modest number of drugs, derived from six antifungal classes, are available. ${ }^{6}$ Among antifungal drugs in clinical use, allylamines (such as terbinafine or naftifine) are active mainly against dermatophytes and act by inhibiting the enzyme squalene epoxidase within the pathway of the biosynthesis of ergosterol, the main sterol of fungal membranes. We reported previously, ${ }^{7-}$ ${ }^{9}$ as part of our ongoing work on antifungal compounds, a group of homoallylamines (i.e., the allyl group is not on the $\mathrm{N}$ atom as in allylamines but on the neighbouring carbon) (Figure 1) that possess good antifungal activities against dermatophytes. For these compounds it was possible to depict the main structural requirements to display antifungal activity on the basis of computational studies. They inhibit some enzymes involved in the synthesis of $1,3-\beta$-glucan and quitin, both main polymers of the fungal cell wall, ${ }^{7-9}$ which interestingly enough, was a different mode of action than that known for allylamines. These previous studies led us to suggest that the allyl group played a key role in the antifungal activity of homoallyl $N$-aryl- $N$-benzylamines and that the position of the allyl group affected their mode of action. ${ }^{8,9}$

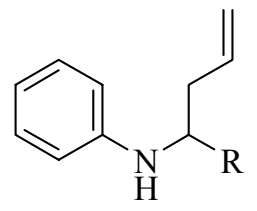

Figure 1. General structure of an antifungal homoallylamine. $\mathrm{R}=$ alkyl, aryl, hetaryl.

Nevertheless, in the last paper of this series ${ }^{9}$ it was envisaged through the observation of a few examples that the elimination of the allyl moiety of homoallylamines (giving place to nonallylic secondary amines) resulted in a slight increase of the antifungal activity. This led to the preparation of series of $\mathrm{N}$-substituted amines bearing a hetaryl fragment (Figure 2) and their antifungal activities were compared to their respective $N$-aryl- $N$-[1-(benzyl)-but-3-enyl]amines analogues, showing that non-allylic structures possessed slightly higher antifungal activity. ${ }^{10}$ Conformational studies suggested that a non-substituted flexible connecting chain could facilitate the binding process to the active site. ${ }^{10}$ Among the tested compounds, 2-furyl substituted anilines showed very good antifungal activities against dermatophytes, particularly against Trichophyton rubrum with MIC $=3.12-6.25 \mu \mathrm{g} / \mathrm{mL}$ ). These results corroborated that the allyl group was not essential for activity in compounds similar to those bearing a homoallyl fragment. 


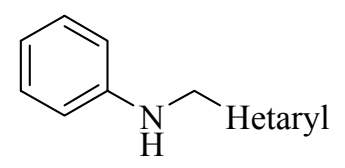

Figure 2. General structures of antifungal $N$-(hetarylmethyl)-anilines.

In this paper we report the preparation, physicochemical and antifungal properties, of a series of ten $\mathrm{N}$-aryl- $\mathrm{N}$-benzylamines 1-10 (Figure 3, Type A) hosting the same substitution patterns with a series of $N$-aryl- $N$-[1-(benzyl)-but-3-enyl]amines (homoallylamines) 11-20 (Type B), with the aim of comparing their antifungal behavior and to determine the role played by the allyl group in the antifungal activity.
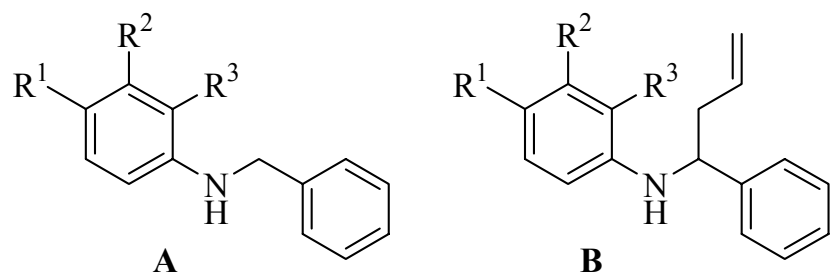

Figure 3. General structures of $N$-aryl- $N$-benzylamines (type A) and $N$-aryl- $N$-[1-(benzyl)-but-3enyl]amines (type B).

\section{Results and Discussion}

\section{Chemistry}

Compounds 1-20 were prepared from commercially available substituted anilines and benzaldehyde, according to reported procedures (Scheme 1). ${ }^{7}$

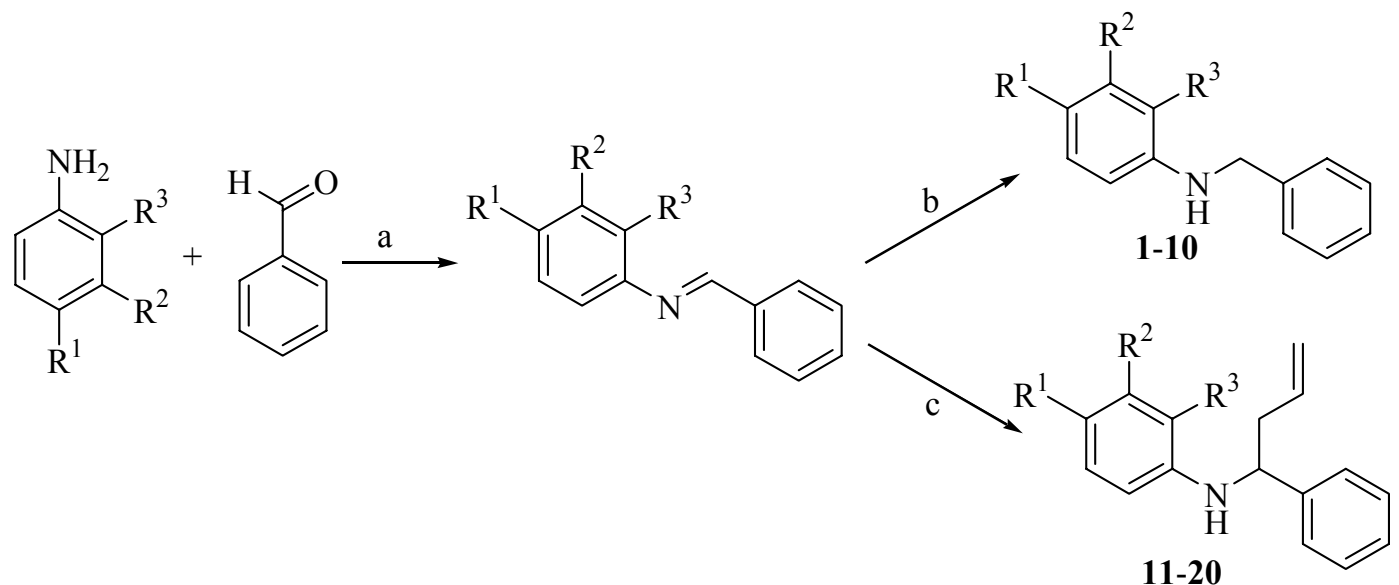

Scheme 1. (a) EtOH, reflux, 5 h; (b) $\mathrm{NaBH}_{4}, \mathrm{MeOH}$, r.t., 2 h; (c) allymagnesium bromide/ $\mathrm{Et}_{2} \mathrm{O}$, $10-24{ }^{\circ} \mathrm{C}$, then $\mathrm{H}_{2} \mathrm{O} / \mathrm{NH}_{4} \mathrm{Cl} /$ ice. 
It is important to take into account that homoallylamines were prepared as racemic mixtures and thus, the activity displayed by compounds 11-20 are due to the mixture of equal amounts of both enantiomers.

\section{Antifungal activity}

The antifungal properties of compounds 1-10 were evaluated by the microbroth dilution method following the guidelines of the M-38 A2 document elaborated by the Clinical and Laboratory Standard Institute (CLSI) and compared to the antifungal activity of the analogues 11-20 (Table 1). ${ }^{11}$

Table 1. Minimum Inhibitory Concentration (MIC) values, in $\mu \mathrm{g} / \mathrm{mL}$

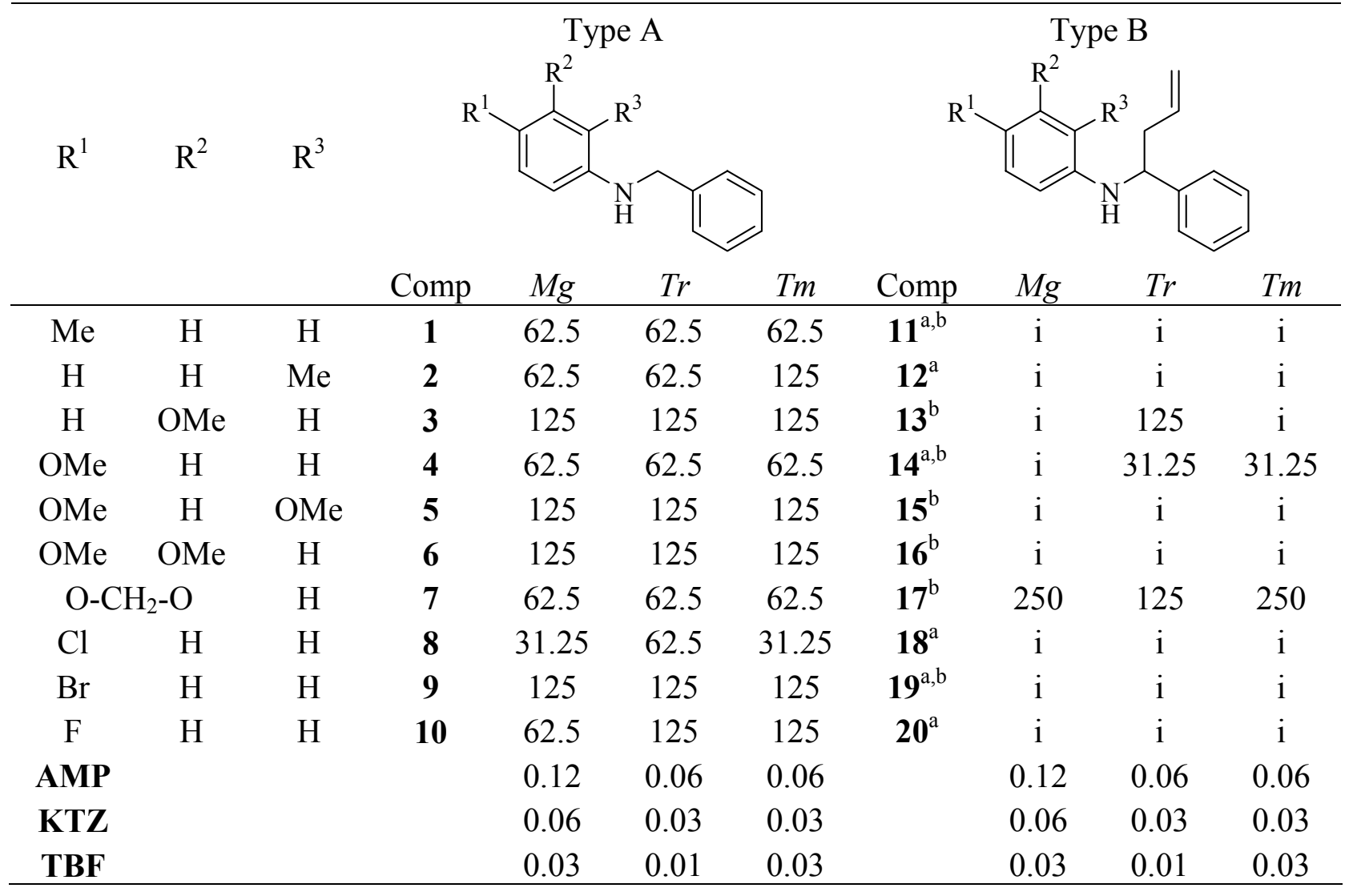

Mg: Microsporum gypseum CCC 115 2000, Tr: Trichophyton rubrum CCC 113 2000, Tm: T. mentagrophytes ATCC 9972. CCC = Culture Collection from Centro de Referencia en Micología (CEREMIC). ATCC: American Type Culture Collection AMP: Amphothericin B, KTZ: Ketoconazole, TBF: Terbinafine. i: inactive $(>250 \mu \mathrm{g} / \mathrm{mL})$. ${ }^{a}$ Activity was previously reported in reference $7 .{ }^{b}$ Activity was previously reported in reference 8 . 
Of the homoallylamines 11-20, only three of the ten compounds evaluated $(13,14$ and 17) displayed antifungal activity against dermatophytes. In contrast, all $N$-aryl- $N$-benzylamines 1-10 were active against the same panel of fungi with $\mathrm{MIC}=31.25-125 \mu \mathrm{g} / \mathrm{mL}$. An exception to this general behavior was observed for compound $\mathbf{4}$ which displayed lower activities against Trichophyton spp. than its homoallyl analogue 14. Since the absence of an allyl chain in amines increases the flexibility of the alkyl chain that connects both rings, the results suggested that the more flexible connecting chain (type A) played a key role in activity, as suggested for the hetaryl analogues. ${ }^{7}$ To give support to this presumption, we performed a comparative conformational study of compounds $\mathbf{8}$ and $\mathbf{1 8}$, which might be regarded as representative molecules of their respective types $\mathrm{A}$ and $\mathrm{B}$. The purpose was to obtain more precise information on how closely non-allylic and allylic $N$-aryl- $N$-benzylamines resemble each other in terms of the spatial orientations of the essential moieties to produce the antifungal activity.

\section{Computational studies}

This study was carried out by using ab initio and DFT calculations. In a first step of our conformational study, we evaluated the torsional angle $\phi_{1}$ in both, the amine $\mathbf{8}$ and the homoallylamine 18 using potential energy curves (PECs). It should be noted that this torsional angle determinates the spatial ordering of rings A (Figure 4).
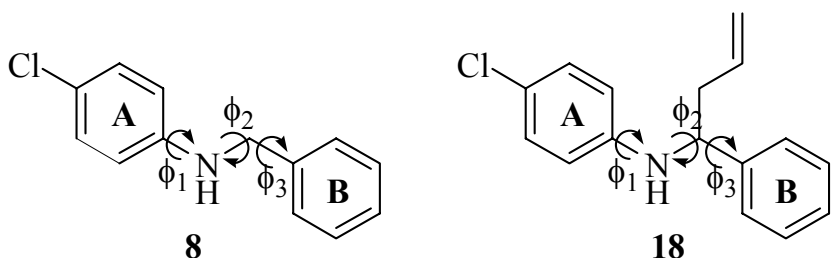

Figure 4. Compounds 8 and $\mathbf{1 8}$ showing the torsional angles of each bond of the connecting chain.

These torsional angles gave characteristic 2-fold periodicity curves with two low-energy conformations at $0^{\circ}$ and $180^{\circ}$ (Figure 5). It is worth to take into account that, due to the symmetry of these compounds, both planar conformers are equivalent.

The torsional angles $\phi_{2}$ and $\phi_{3}$ were evaluated from potential energy surfaces (PESs) scanning $\phi_{2}$ versus $\phi_{3}$ each $30^{\circ}$ (Figure 6). A comparison of Figures 6a and 6b clearly showed that compounds $\mathbf{8}$ and $\mathbf{1 8}$ possessed very different conformations. Whereas $\mathbf{8}$ displayed the preferred conformers located in a conformational space from $0^{\circ}$ to $60^{\circ}$ and $200^{\circ}$ to $360^{\circ}$ possessing the conformers of the highest energy in the zone from $90^{\circ}$ to $180^{\circ}$ (Figure 6a), 18 displayed a restricted zone from $50^{\circ}$ to $180^{\circ}$ for the low-energy conformations (note that the preferred conformations of $\mathbf{1 8}$ are located exactly in the conformational space of high energy for 8. Next we optimized the different conformations obtained for $\mathbf{8}$ and $\mathbf{1 8}$ using DFT [B3LYP/6$31 \mathrm{G}(\mathrm{d})]$ calculations. These results are summarized in the Supplementary Material. 

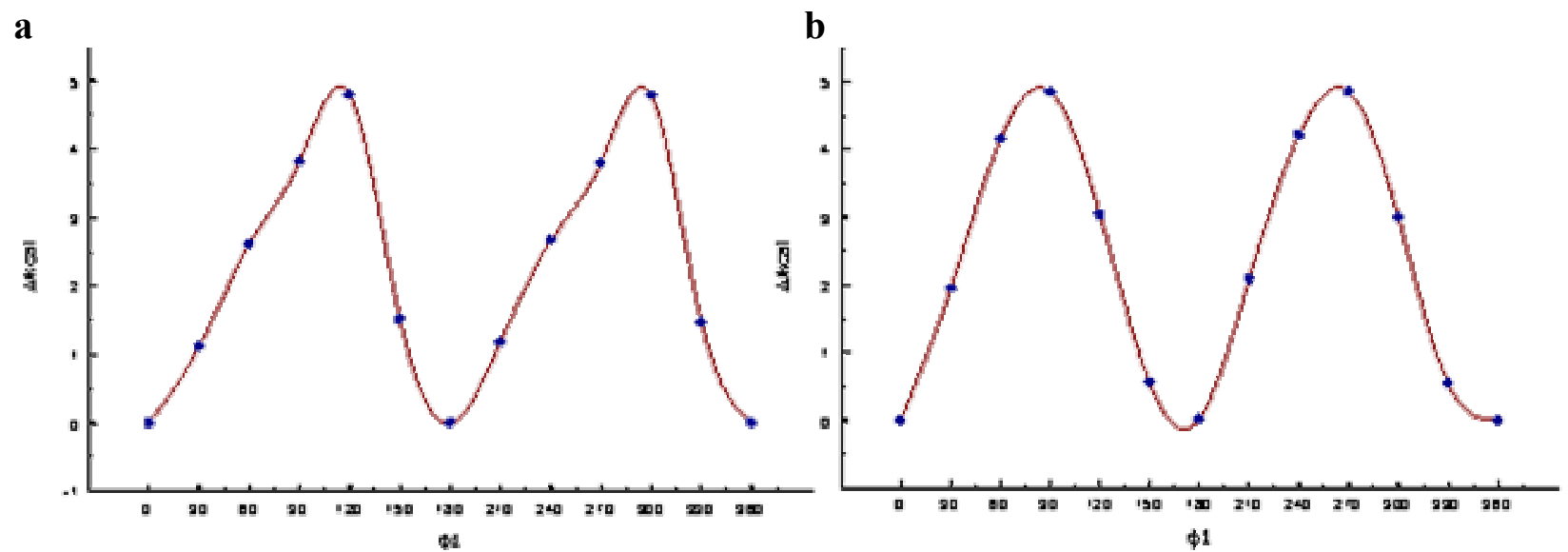

Figure 5. Potential Energy Curves (PECs) of torsional angles $\phi_{1}$ obtained for compounds 8 (a) and 18 (b). Each PEC was calculated at RHF/3-21G level of theory.

On the other hand from Figure 6 it was also possible to appreciate that the molecular flexibility of compound $\mathbf{8}$ was significantly higher than that obtained for compound $\mathbf{1 8}$ (note the different sizes of the red zones in the contour diagrams and the different dips and slopes of the valleys). Thus, the surface of compound $\mathbf{8}$ (Figure $6 \mathrm{a}$ ) showed that all possible interconversions among the conformers may follow very low-energy paths (note the extensive red zones in this PES). The surface for compound 18 (Figure 6b) was quite different. In this case high-energy barriers characterize the overall process. To better appreciate such results, the iso-energy curves included in an energy window of $4 \mathrm{kcal} / \mathrm{mol}$ were denoted in red.

Figure 7 gives a superimposed spatial view of the two energetically preferred forms obtained for 8 and 18. The different conformations adopted by these compounds might be well appreciated in this Figure. The superposition of both the A ring and the $\mathrm{N}$ atom was complete, while the position of ring $\mathrm{B}$ was quite different. In compound $\mathbf{8}$ rings $\mathrm{A}$ and $\mathrm{B}$ were located in an extended conformation. Instead, in compound $\mathbf{1 8}$ the position of the allyl moiety prevented it from adopting a similar conformation.

Once the conformational behaviours of $\mathbf{8}$ and $\mathbf{1 8}$ had been analyzed, an electronic analysis of their respective conformations by using Electrostatic Potentials Maps (MEP's) was performed. 
a

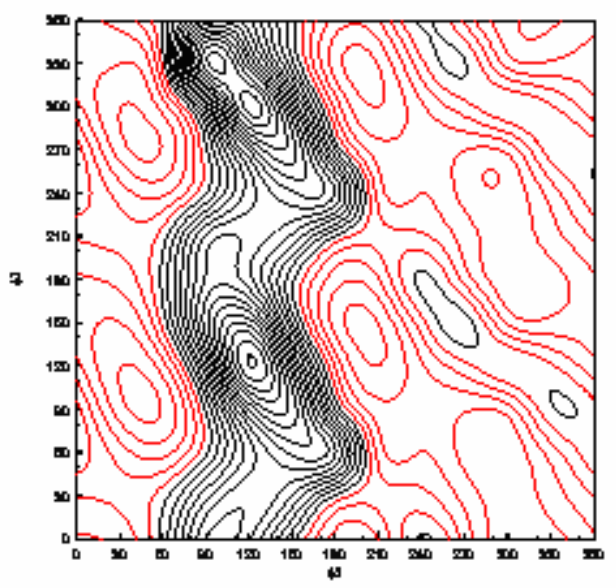

b

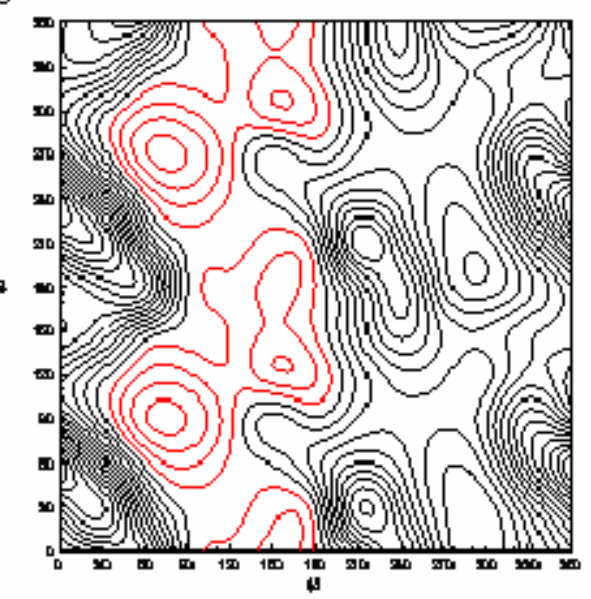

Figure 6. Contour graphic of the PES obtained for compounds 8 (a) and 18 (b) from RHF/3-21G calculations. Full cycle of rotation (from $0^{\circ}$ to $360^{\circ}$ ) is shown for variables $\phi_{2}$ and $\phi_{3}$. The isoenergy curves included in an energy window of $4 \mathrm{kcal} / \mathrm{mol}$ are denoted in red.

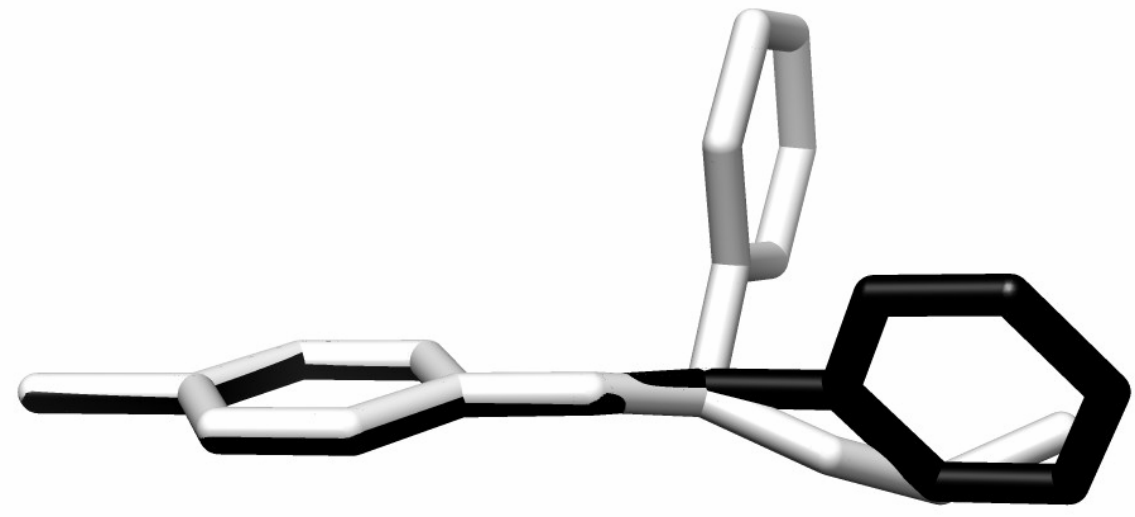

Figure 7. Stereoview of overlapping of global minimums for 8 (black) and 18 (light gray).

Figure 8 gave the MEP's obtained for these compounds. The MEP's exhibited one region with negative potentials. The minimum of lowest energy (deep red zone) is located in the region of A ring. The V(r)min $-0.18 \mathrm{el} / \mathrm{au}^{3}$ values in the benzene of A ring by both compounds. Also there was a single hydrophobic region in both, but much higher in 18. This was an expected result, because this compound has a group allylamine that increased the size of the hydrophobic portion. These effects might be well appreciated in Figure 8.

The surfaces were generated with GAUSSIAN 03 using RHF/6-31G single point calculations. The coloring represents electrostatic potential with red indicating the strongest attraction to a positive point charge and blue indicating the strongest repulsion. The electrostatic potential is the energy of interaction of the positive point charge with the nuclei and electrons of 
a molecule. It provides a representative measure of overall molecular charge distribution. The color-code is shown at the left.

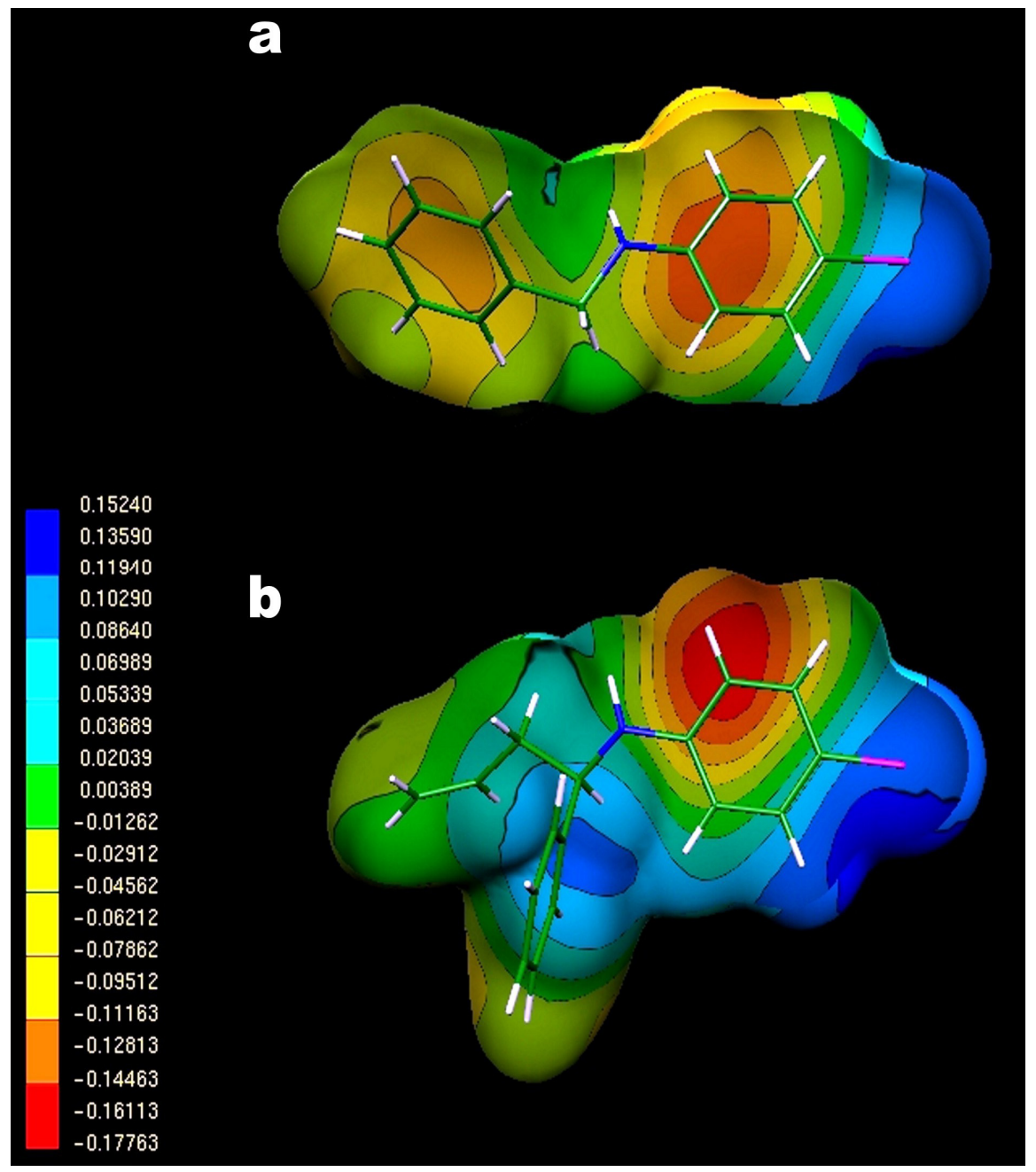

Figure 8. Electrostatic potential-encoded electron density surfaces of compound $\mathbf{8}$ (a) and $\mathbf{1 8}$ (b).

Our theoretical calculations confirmed that the most active compounds type A possessed a higher flexibility which should be an important feature for the antifungal behavior. The global minima optimized from DFT calculations indicate that the spatial ordering adopted by $\mathbf{1 8}$ was quite different from that obtained for $\mathbf{8}$. These results were in accordance with our preliminary observation that the presence of the allyl group in the flexible connecting chain caused a dramatic decrease in the antifungal activity of homoallylamines. ${ }^{2,3}$ 


\section{Experimental Section}

General. Melting points were obtained in a Electrothermal apparatus (U.K.) and were uncorrected; ${ }^{.1} \mathrm{H}$ and ${ }^{13} \mathrm{C}$ NMR spectra were recorded on a Bruker $300 \mathrm{MHz}$ (Karlsruhe, Germany) instrument with $\mathrm{CDCl}_{3}$ as solvent and TMS as internal standard. Chemical shifts are reported in ppm $(\delta)$ relative to the solvent peak $\left(\mathrm{CHCl}_{3}\right.$ in $\mathrm{CDCl}_{3}$ at $7.26 \mathrm{ppm}$ for protons and at 77.0 ppm for carbons). Signals are designated as follows: s, singlet; d, doublet; t, triplet; dd, doublets of doublets; dt, doublets of triplets; m, multiplet; bs broad singlet. ESI-HRMS spectra were recorded on a Bruker MicrOTOF Q-II mass spectrometer in positive mode. Elemental analyses were performed on a Carlo Erba EA 1108 analyzer (Milano, Italy). Percentages of C, H and $\mathrm{N}$ were in agreement with the product formula. Solvents, benzaldehyde and substituted anilines were purchased from Sigma Aldrich and used without further purification.

\section{Chemistry}

Both, type A and type B compounds were synthesized from aldimines that were prepared from commercially benzaldehyde and substituted anilines, according to published methods (scheme 1). Then, type A $N$-aryl- $N$-benzylamines 1-10 were synthesized through the reduction of aldimines using an excess of $\mathrm{NaBH}_{4}$ in methanol followed by purification using $\mathrm{SiO}_{2}$ chromatography column. ${ }^{10}$ The type B series $\{N$-aryl- $N$-[1-(benzyl)-but-3-enyl]amines 11-20 $\}$ was obtained by nucleophilic addition of preformed allylmagnesium bromide to the $\mathrm{C}=\mathrm{N}$ bond of respective aldimines followed by purification using $\mathrm{SiO}_{2}$ chromatography column. ${ }^{8}$ Compounds 11-20 were previously reported. 7,8

$\boldsymbol{N}$-(2-Methylphenyl)- $\boldsymbol{N}$-benzylamine (1). Yellow needles, mp 59-60 ${ }^{\circ} \mathrm{C}$ (lit. ${ }^{11} 59.5-61.0{ }^{\circ} \mathrm{C}$ ) (from ethyl ether). ${ }^{1} \mathrm{H} \mathrm{NMR}\left(300 \mathrm{MHz}, \mathrm{CDCl}_{3}\right) \delta 2.21\left(3 \mathrm{H}, \mathrm{s}, \mathrm{CH}_{3}\right), 3.89(1 \mathrm{H}, \mathrm{bs}, \mathrm{NH}), 4.41$ $(2 \mathrm{H}, \mathrm{s}, \mathrm{CH}), 6.63-6.75\left(2 \mathrm{H}, \mathrm{m}, H_{\mathrm{AR}}\right), 706-7.46\left(7 \mathrm{H}, \mathrm{m}, H_{\mathrm{AR}}\right) \cdot{ }^{13} \mathrm{C} \mathrm{NMR}\left(65.5 \mathrm{MHz}, \mathrm{CDCl}_{3}\right) \delta$ $17.7,48.4,110.1,117.3,125.8,127.6,128.8,128.9,130.2,130.4,139.6,146.2$. HRMS-ESI $m / z$ 198.1286 (calcd. for $\mathrm{C}_{14} \mathrm{H}_{15} \mathrm{~N}[\mathrm{M}+\mathrm{H}]^{+}, 198.1277$ ); anal. C, 85.4; $\mathrm{H}, 7.8 ; \mathrm{N}, 7.0$; calcd for $\mathrm{C}_{14} \mathrm{H}_{15} \mathrm{~N}$ : C, 85.3; H, 7.6; N, 7.1\%.

$\boldsymbol{N}$-(4-Methyl-phenyl)- $\boldsymbol{N}$-benzylamine (2). Yellow oil. ${ }^{12-13}{ }^{1} \mathrm{H}$ NMR $\left(300 \mathrm{MHz}, \mathrm{CDCl}_{3}\right) \delta 2.31$ $\left(3 \mathrm{H}, \mathrm{s}, \mathrm{CH}_{3}\right), 4.36\left(2 \mathrm{H}, \mathrm{s}, \mathrm{CH}_{2}\right), 6.62(2 \mathrm{H}, \mathrm{d}, J 8.4 \mathrm{~Hz}, 3,5-H), 7.05(2 \mathrm{H}, \mathrm{d}, J 7.9 \mathrm{~Hz}, 2,6-H)$, 7.21-7,51 (5H, m, $\left.H_{\mathrm{AR}}\right) .{ }^{13} \mathrm{C} \mathrm{NMR}\left(65.5 \mathrm{MHz}, \mathrm{CDCl}_{3}\right) \delta 20.5,48.7,113.1,125.8,126.8,127.6$, 128.7, 129.8, 139.8, 146.2. HRMS-ESI $m / z 198.1283$ (calcd. for $\mathrm{C}_{14} \mathrm{H}_{15} \mathrm{~N}[\mathrm{M}+\mathrm{H}]^{+}, 198.1277$ ); anal. C, 85.2; H, 7.8; N, 7.0; calcd for $\mathrm{C}_{14} \mathrm{H}_{15} \mathrm{~N}$ : C, 85.3; H, 7.6; N, 7.1\%.

$\boldsymbol{N}$-(3-Methoxyphenyl)- $\boldsymbol{N}$-benzylamine (3). Yellow oil. ${ }^{14-15}{ }^{1} \mathrm{H}$ NMR (300 $\left.\mathrm{MHz}, \mathrm{CDCl}_{3}\right) \delta 3.77$ $\left(3 \mathrm{H}, \mathrm{s}, \mathrm{OCH}_{3}\right), 4.06(1 \mathrm{H}, \mathrm{bs}, \mathrm{NH}), 4.33\left(2 \mathrm{H}, \mathrm{s}, \mathrm{CH}_{2}\right), 6.22(1 \mathrm{H}, \mathrm{t}, J 2.2 \mathrm{~Hz}, 2-H), 6.30(2 \mathrm{H}, \mathrm{dt}, J$ 2.2, $9.0 \mathrm{~Hz}, 4-H), 7.10(2 \mathrm{H}, \mathrm{t}, J 2.2,9.8 \mathrm{~Hz}, 5-H), 7.24-7.50\left(5 \mathrm{H}, \mathrm{m}, H_{\mathrm{Ar}}\right) .{ }^{13} \mathrm{C} \mathrm{NMR}(65.5 \mathrm{MHz}$, $\left.\mathrm{CDCl}_{3}\right) \delta 48.7,55.1,98.9,102.7,106.1,127.3,127.6,128.7,130.1,139.4,149.6,160.9$. HRMSESI $m / z 214.1218$ (calcd. for $\mathrm{C}_{14} \mathrm{H}_{15} \mathrm{NO}[\mathrm{M}+\mathrm{H}]^{+}, 214.1226$ ); anal. $\mathrm{C}, 78.7 ; \mathrm{H}, 7.1 ; \mathrm{N}$, 6.7; calcd for $\mathrm{C}_{14} \mathrm{H}_{15} \mathrm{NO}$ : C, 78.9; $\mathrm{H}, 7.0 ; \mathrm{N}, 6.6 \%$. 
$\boldsymbol{N}$-(4-Methoxyphenyl)- $\boldsymbol{N}$-benzylamine (4). Yellow-brown needles, mp 51-52 ${ }^{\circ} \mathrm{C}$ (lit. ${ }^{16}$ 50-51 ${ }^{\circ} \mathrm{C}$ ) (from ethyl ether). ${ }^{1} \mathrm{H} \mathrm{NMR}\left(300 \mathrm{MHz}, \mathrm{CDCl}_{3}\right) \delta 3.75\left(3 \mathrm{H}, \mathrm{s}, \mathrm{OCH}_{3}\right), 4.30\left(2 \mathrm{H}, \mathrm{s}, \mathrm{CH}_{2}\right)$, 6.58-6.68 $(2 \mathrm{H}, \mathrm{m}, 2,6-H), 6.73-6.83(2 \mathrm{H}, \mathrm{m}, 3,5-H), 7.21-7.47\left(5 \mathrm{H}, \mathrm{m}, H_{\mathrm{Ar}}\right) .{ }^{13} \mathrm{C} \mathrm{NMR}(65.5$ $\left.\mathrm{MHz}, \mathrm{CDCl}_{3}\right) \delta 49.2,55.8,114.1,114.9,127.2,127.6,128.6,139.7,142.5,152.2$. HRMS -ESI $m / z 214.1230$ (calcd. for $\mathrm{C}_{14} \mathrm{H}_{15} \mathrm{NO}[\mathrm{M}+\mathrm{H}]^{+}, 214.1226$ ); anal. C, 78.8; H, 6.9; N, 6.6; calcd for $\mathrm{C}_{14} \mathrm{H}_{15} \mathrm{NO}$ : C, 78.9; H, 7.0; N, 6.6\%.

$\boldsymbol{N}$-(2,4-Dimethoxyphenyl)- $\boldsymbol{N}$-benzylamine (5). Yellow oil. ${ }^{17}{ }^{1} \mathrm{H}$ NMR (300 $\left.\mathrm{MHz}, \mathrm{CDCl}_{3}\right) \delta$ $3.75\left(3 \mathrm{H}, \mathrm{s}, \mathrm{OCH}_{3}\right), 3.83\left(3 \mathrm{H}, \mathrm{s}, \mathrm{OCH}_{3}\right), 4.31\left(2 \mathrm{H}, \mathrm{s}, \mathrm{CH}_{2}\right), 6.34(1 \mathrm{H}, \mathrm{dd}, J 2.6,8.5,6-H), 6.48$ $(1 \mathrm{H}, \mathrm{d}, J 2.6,3-H), 6.52(1 \mathrm{H}, \mathrm{d}, J 8.5,5-H), 7.21-7.43\left(5 \mathrm{H}, \mathrm{m}, H_{\mathrm{Ar}}\right) .{ }^{13} \mathrm{C} \mathrm{NMR}(65.5 \mathrm{MHz}$, $\left.\mathrm{CDCl}_{3}\right) \delta 48.8,55.5,55.8,99.2,103.7,110.3,127.1,127.6,128.6,132.6,139.9,147.9,151.9$. HRMS-ESI $m / z 244.1329$ (calcd. for $\mathrm{C}_{15} \mathrm{H}_{17} \mathrm{NO}_{2}[\mathrm{M}+\mathrm{H}]^{+}, 244.1332$ ); anal. C, 73.9; H, 7.1; N, 5.9; calcd for $\mathrm{C}_{15} \mathrm{H}_{17} \mathrm{NO}_{2}$ : C, 74.1; $\mathrm{H}, 7.0 ; \mathrm{N}, 5.8$.

$\boldsymbol{N}$-(3,4-Dimethoxyphenyl)- $\boldsymbol{N}$-benzylamine (6). Yellow-brown needles, mp $81-83{ }^{\circ} \mathrm{C}$ (lit. ${ }^{18} 83$ $86.5{ }^{\circ} \mathrm{C}$ ) (from ethanol 95\%). ${ }^{1} \mathrm{H}$ NMR $\left(300 \mathrm{MHz}, \mathrm{CDCl}_{3}\right) \delta 3.80\left(3 \mathrm{H}, \mathrm{s}, \mathrm{OCH}_{3}\right), 3.81(3 \mathrm{H}, \mathrm{s}$, $\left.\mathrm{OCH}_{3}\right), 4.29\left(2 \mathrm{H}, \mathrm{s}, \mathrm{CH}_{2}\right), 6.18(1 \mathrm{H}, \mathrm{dd}, J 2.6,8.5,6-H), 6.28(1 \mathrm{H}, \mathrm{d}, J 2.5,2-\mathrm{H}), 6.74(1 \mathrm{H}, \mathrm{d}, J$ 8.5, 5-H), 7.25-7.42 (5H, m, $\left.\mathrm{H}_{\mathrm{Ar}}\right) .{ }^{13} \mathrm{C} \mathrm{NMR}\left(65.5 \mathrm{MHz}, \mathrm{CDCl}_{3}\right) \delta 49.2,55.7,56.7,99.0,103.9$, 113.3, 127.2, 127.6, 128.6, 139.6, 141.7, 143.2, 150.0. HRMS-ESI $m / z 244.1324$ (calcd. for $\left.\mathrm{C}_{15} \mathrm{H}_{17} \mathrm{NO}_{2}[\mathrm{M}+\mathrm{H}]^{+}, 244.1332\right)$; anal. $\mathrm{C}, 74.2 ; \mathrm{H}, 7.1 ; \mathrm{N}, 5.7$; calcd for $\mathrm{C}_{15} \mathrm{H}_{17} \mathrm{NO}_{2}$ : C, 74.1; H, 7.0; N, 5.8\%.

$\boldsymbol{N}$-(3,4-Methylendioxyphenyl)- $\boldsymbol{N}$-benzylamine (7). Yellow-brown needles, mp $83-85{ }^{\circ} \mathrm{C}$ (lit. ${ }^{19}$ $81-83^{\circ} \mathrm{C}$ ) (from ethanol 95\%). ${ }^{1} \mathrm{H}$ NMR $\left(300 \mathrm{MHz}, \mathrm{CDCl}_{3}\right) \delta 4.27\left(2 \mathrm{H}, \mathrm{s}, \mathrm{CH}_{2}\right), 5.85(2 \mathrm{H}, \mathrm{s}$, $\left.\mathrm{OCH}_{2} \mathrm{O}\right), 6.08(1 \mathrm{H}, \mathrm{dd}, J 2.3,8.3,6-H), 6.27(1 \mathrm{H}, \mathrm{d}, J 2.3,2-H), 6.65(1 \mathrm{H}, \mathrm{d}, J 8.3,5-H), 7.25-$ $7.38\left(5 \mathrm{H}, \mathrm{m}, H_{\mathrm{Ar}}\right) .{ }^{13} \mathrm{C} \mathrm{NMR}\left(65.5 \mathrm{MHz}, \mathrm{CDCl}_{3}\right) \delta 49.3,96.0,100.6,104.4,108.7,127.2,127.5$, 128.7, 139.4, 139.7, 143.9, 148.3. HRMS-ESI $m / z 228.1017$ (calcd. for $\mathrm{C}_{14} \mathrm{H}_{13} \mathrm{NO}_{2}[\mathrm{M}+\mathrm{H}]^{+}$, 228.1019); anal. C, 74.2; H, 6.0; N, 6.2; calcd for $\mathrm{C}_{14} \mathrm{H}_{13} \mathrm{NO}_{2}$ : C, 74.0; H, 5,8; N, 6.2\%.

$\boldsymbol{N}$-(4-Chlorophenyl)- $\boldsymbol{N}$-benzylamine (8). Yellow oil. ${ }^{13}{ }^{1} \mathrm{H}$ NMR $\left(300 \mathrm{MHz}, \mathrm{CDCl}_{3}\right) \delta 4.07(1 \mathrm{H}$, bs, NH), $4.31\left(2 \mathrm{H}, \mathrm{s}, \mathrm{CH}_{2}\right), 6.55(2 \mathrm{H}, \mathrm{d}, J 8.8 \mathrm{~Hz}, 2,6-H), 7.11(2 \mathrm{H}, \mathrm{d}, J 8.8 \mathrm{~Hz}, 3,5-H), 7.25-$ $7.37\left(5 \mathrm{H}, \mathrm{m}, H_{\mathrm{Ar}}\right) .{ }^{13} \mathrm{C} \mathrm{NMR}\left(65.5 \mathrm{MHz}, \mathrm{CDCl}_{3}\right) \delta 48.3,113.9,122.0,127.3,127.6,127.7$, 129.0, 138.9, 146.5. HRMS-ESI $m / z 218.0731$ (calcd. for $\mathrm{C}_{13} \mathrm{H}_{12} \mathrm{ClN}[\mathrm{M}+\mathrm{H}]^{+}, 218.0731$ ); anal. C, 71.6; H, 5.5; N, 6.5; calcd for $\mathrm{C}_{13} \mathrm{H}_{12} \mathrm{ClN}$ : C, 71.8; H, 5.5; N, 6.4\%.

$\mathrm{N}$-(4-Bromophenyl)- $\mathrm{N}$-benzylamine (9). Yellow prisms. mp: $52-53{ }^{\circ} \mathrm{C}$ (lit. ${ }^{16} 51-52{ }^{\circ} \mathrm{C}$ ) (from ethyl ether). ${ }^{1} \mathrm{H}$ NMR $\left(300 \mathrm{MHz}, \mathrm{CDCl}_{3}\right) \delta 4.08(1 \mathrm{H}, \mathrm{bs}, \mathrm{NH}), 4.31\left(2 \mathrm{H}, \mathrm{s}, \mathrm{CH}_{2}\right), 6.51(2 \mathrm{H}, \mathrm{d}, J$ $8.8 \mathrm{~Hz}, 2,6-H), 7.25(2 \mathrm{H}, \mathrm{d}, J 8.8 \mathrm{~Hz}, 3,5-H), 7.28-7.40\left(5 \mathrm{H}, \mathrm{m}, H_{\mathrm{Ar}}\right) .{ }^{13} \mathrm{C} \mathrm{NMR}(65.5 \mathrm{MHz}$, $\left.\mathrm{CDCl}_{3}\right) \delta 48.3,109.1,114.4,116.7,127.4,128.7,131.9,138.9,147.0 . \mathrm{MS} m / z 261(100 \%), 263$ (97\%); anal. C, 59.8; H, 4.5; N, 5.2; calcd for $\mathrm{C}_{13} \mathrm{H}_{12} \mathrm{BrN}$ : C, 59.6; H, 4.6; N, 5.3\%.

$\boldsymbol{N}$-(4-Fluorophenyl)- $\boldsymbol{N}$-benzylamine (10). Yellow prisms. mp: $33-35{ }^{\circ} \mathrm{C}$ (lit. ${ }^{16} 32-33{ }^{\circ} \mathrm{C}$; lit. $^{20}$ $35-36{ }^{\circ} \mathrm{C}$ ) (from ethanol 95\%). ${ }^{1} \mathrm{H}$ NMR $\left(300 \mathrm{MHz}, \mathrm{CDCl}_{3}\right) \delta 4.01(1 \mathrm{H}, \mathrm{bs}, \mathrm{N} H), 4.35(2 \mathrm{H}, \mathrm{s}$, $\left.\mathrm{CH}_{2}\right), 6.51-6.74(2 \mathrm{H}, \mathrm{m}, 2,6-H), 7.84-7.09(2 \mathrm{H}, \mathrm{m}, 3,5-H), 7.12-7.64\left(5 \mathrm{H}, \mathrm{m}, H_{\mathrm{AR}}\right) .{ }^{13} \mathrm{C}$ NMR $\left(65.5 \mathrm{MHz}, \mathrm{CDCl}_{3}\right) \delta 48.9,113.7(\mathrm{~d}, J 7.2), 115.7(\mathrm{~d}, J 22.0), 127.4,127.6,128.8,139.4,144.7$, 
154.4, 157.5. HRMS-ESI $m / z 202.1022$ (calcd. for $\mathrm{C}_{13} \mathrm{H}_{12} \mathrm{FN}[\mathrm{M}+\mathrm{H}]^{+}$, 202.1026); anal. C, 77.8; $\mathrm{H}, 6.1 ; \mathrm{N}, 6.9$; calcd for $\mathrm{C}_{13} \mathrm{H}_{12} \mathrm{FN}$ : C, 77.6; $\mathrm{H}, 6.0 ; \mathrm{N}, 7.0 \%$.

\section{Biological evaluation}

For the antifungal evaluation, Microsporum gypseum CCC 115 2000, Trichophyton rubrum CCC 1132000 and T. mentagrophytes ATCC 9972. were obtained from the Culture Collection of CEREMIC (CCC), Centro de Referencia en Micología, Facultad de Ciencias Bioquímicas y Farmacéuticas, Suipacha 531-(2000)-Rosario, Argentina and the American Type Culture Collection (ATCC), Rockville, MD, USA. Strains were grown on Sabouraud-chloramphenicol agar slants for $48 \mathrm{~h}$ at $30{ }^{\circ} \mathrm{C}$, maintained on slopes of Sabouraud-dextrose agar (SDA, Oxoid), and subcultured every 15 days to prevent pleomorphic transformations. Inocula of conidia suspensions were obtained according to reported procedures ${ }^{21}$ and adjusted to $1-5 \times 10^{3}$ spores with colony forming units $(\mathrm{CFU}) / \mathrm{mL}$.

The Minimum Inhibitory Concentration (MIC) of each compound was determined by using broth microdilution techniques following the guidelines of the M-38A2 CLSI for filamentous fungi. ${ }^{21}$ MIC values were determined in RPMI-1640 (Sigma, St. Louis, MO, USA) buffered to $\mathrm{pH} 7.0$ with MOPS. Microtiter trays were incubated at $28-30^{\circ} \mathrm{C}$ in a moist, dark chamber; MICs were recorded at 7 days.

For the assay, compound stock solutions were 2-fold diluted with RPMI-1640 from 250 to $0.98 \mu \mathrm{g} / \mathrm{ml}$ (final volume $=100 \mu \mathrm{l}$ ) and a final DMSO concentration $\leq 1 \%$. A volume of $100 \mu \mathrm{l}$ of inoculum suspension was added to each well with the exception of the sterility control where sterile water was added to the well instead. The standard drugs Ketoconazole, Terbinafine, and Amphotericin B were evaluated as positive controls. The MIC was defined as the minimum inhibitory concentration of the compound, which resulted in total inhibition of the fungal growth.

\section{Calculation methods}

All calculations were carried out using the Gaussian 03 program. ${ }^{22}$ The search for the low-energy conformation for compounds $\mathbf{8}$ and $\mathbf{1 8}$ was carried out by using ab initio calculations (HF/321g). Subsequently, Density Functional Theory (DFT) with the Becke-3-Lee-Yang-Parr (RB3LYP) functional ${ }^{23-25}$ and 6-31G(d) basis set calculations were used in the optimisation jobs of minimum obtained from Potential Energy Surface (PES).

Compounds reported here possess one chiral center and therefore they are enantiomeric with the possibility of two isomers $(R$ and $S$ ). However, we did not perform an enantiomeric resolution for the biological assays. It should be noted that only one isomer of each compound was evaluated in our calculations. To choose one of the isomeric forms for these compounds, we take into account preliminary and exploratory calculations performed for compound 18. These preliminary and exploratory calculations indicated that the spatial ordering adopted by the $R$ form is energetically preferred by $2.5 \mathrm{kcal} / \mathrm{mol}$ [at B3LYP/6-31G (d) level] with respect to the $S$ isomer. Thus, we chose the $R$ forms in our computations. It must be pointed out that our principal goal with these calculations was to obtain information about the conformational and electronic 
aspects of the molecules. Specifically, we were particularly interested in the different molecular flexibility as well as in the electronic distributions and therefore for such purposes both enantiomers could be operative.

The electronic study of compounds $\mathbf{8}$ and $\mathbf{1 8}$ was carried out using molecular electrostatic potentials (MEPs). ${ }^{26}$ The low-energy conformations were obtained for these compounds from our conformational search. Subsequently, single point calculations were carried out. Thus, these MEPs were calculated using B3LYP/6-311++G(d,p) wave functions and MEPs graphical presentations were created using the MOLEKEL program. ${ }^{27}$ The overlapping graphics images were produced using the UCSF Chimera package. ${ }^{28}$

\section{Acknowledgements}

FG and MS acknowledge CONICET for postdoctoral fellowships. SZ thanks to ANPCyT and UNR. RDE belongs to the research career from CONICET. Authors acknowledge the Resource for Biocomputing, Visualization, and Informatics at the University of California, San Francisco (supported by NIH P41 RR-01081) for the overlapping graphics.

\section{References}

1. Petrikkos, G.; Skiada, A. Intern. J. Antimicrob. Agents 2007, 30, 108.

2. Mathew, B.; Nath, M. Chem. Med. Chem. 2009, 4, 310.

3. Monk, B.; Goffeau, A. Science 2008, 321, 367.

4. Weitzman, I.; Summerbell, R. Clin. Microbiol. Rev. 1995, 8, 240.

5. Freixa, B.; Vila, R.; Vargas, L.; Lozano, N.; Adzet, T.; Cañigueral, S. Phytother. Res. 1998, $10,427$.

6. Cowen, L.; Singh, S.; Köhler, J.; Collins, C.; Zaas, A.; Schell, W.; Aziz, H.; Mylonakis, E.; Perfect, J.; Whitesell, L.; Lindquist, S. Proc. Nat. Acad. Sci. (PNAS) 2009, 106, 2818.

7. Urbina, J.; Cortés, J.; Palma, A.; López, S.; Zacchino, S.; Enriz, R.; Ribas, J.; Kouznetsov, V. Bioorg. Med. Chem. 2000, 8, 691.

8. Vargas, L.; Castelli, M.; Kouznetsov, V.; Urbina. J.; López, S.; Sortino, M.; Enriz, R.; Ribas, J.; Zacchino, S. Bioorg. Med. Chem. 2003, 11, 1531.

9. Suvire, F.; Sortino, M.; Kouznetsov, V.; Vargas, L.; Zacchino, S.; Enriz, R. Bioorg. Med. Chem. 2006, 14, 1851.

10. Kouznetsov, V.; Vargas, L.; Sortino, M.; Vásquez, Y.; Gupta, M.; Freile, M.; Enriz, R.; Zacchino, S. Bioorg. Med. Chem. 2008, 16, 794.

11. Miyano, S. Chem. Pharm. Bull. 1966, 14, 731.

12. Kirsanov, A. Bull. Soc. Chim. France, Memoires 1935, 2, 2109.

13. Watanabe, Y.; Tsuji, Y.; Ige, H.; Ohsugi, Y.; Ohta, T. J. Org. Chem. 1984, 49, 3359. 
14. Sydnes, M.; Kuse, M.; Isobe, M. Tetrahedron 2008, 64, 6406.

15. Shen, Q.; Ogata T.; Hartwig, J. J. Am. Chem. Soc. 2008, 130, 6586.

16. Roe, A.; Montgomery, J. J. Am. Chem. Soc. 1953, 20, 910.

17. Barton, D.; Donnelly, D.; Finet, J.; Guiry, P. J. Chem. Soc. Perkin Trans. I 1991, 9, 2095.

18. Jula, M.; Igolen, J.; Igolen, H. Bull. Soc. Chim. France. 1962, 1060.

19. Sreedhar, B.; Surendra Reddy, P.; Keerthi Devi, D. J. Org. Chem. 2009, 74, 8806.

20. Froehling, D.; Pohloudek, R. Archiv. Pharm. 1965, $298,617$.

21. CLSI, Clinical and Laboratory Standards Institute Document M38-A2. Reference method for broth dilution antifungal susceptibility testing of filamentous fungi. Approved Standardsecond edition. Wayne: Pennsylvania, 2008.

22. Frisch, M.; Trucks, G.; Schlegel, H.; Scuseria, G.; Robb, M.; Cheeseman, J.; Montgomery, J. Jr.; Vreven, T.; Kudin, K.; Burant, J.; Millam, J.; Iyengar, S.; Tomasi, J.; Barone, V.; Mennucci, B.; Cossi, M.; Scalmani, G.; Rega, N.; Petersson, G.; Nakatsuji, H.; Hada, M.; Ehara, M.; Toyota, K.; Fukuda, R.; Hasegawa, J.; Ishida, M.; Nakajima, T.; Honda, Y.; Kitao, O.; Nakai, H.; Klene, M.; Li, X.; Knox, J.; Hratchian, H.; Cross, J.; Adamo, C.; Jaramillo, J.; Gomperts, R.; Stratmann, R.; Yazyev, O.; Austin, A.; Cammi, R.; Pomelli, C.; Ochterski, J.; Ayala, P.; Morokuma, A.; Voth, G.; Salvador, P.; Dannenberg, J.; Zakrzewski, V.; Dapprich, S.; Daniels, A.; Strain, M.; Farkas, O.; Malick, D.; Rabuck, A.; Raghavachari, K.; Foresman, J.; Ortiz, J.; Cui, Q.; Baboul, A.; Clifford, S.; Cioslowski, J.; Stefanov, B.; Liu, G.; Liashenko, A.; Piskorz, P.; Komaromi, I.; Martin, R.; Fox, D.; Keith, T.; Al-Laham, M.; Peng, C.; Nanayakkara, A.; Challacombe, M.; Gill, P.; Johnson, B.; Chen, W.; Wong, M.; Gonzalez, C.; Pople, J. Gaussian 03, Revision B.05. Gaussian, Inc.: Pittsburgh PA, 2003.

23. Becke, A. Phys. Rev. A 1988, 38, 3098.

24. Becke, A. J. Chem. Phys. 1993, 98, 5648.

25. Lee, C.; Yang, W.; Parr, R. Phys. Rev. B 1988, 37, 785.

26. Politzer, P.; Daiker, K.C. In The Force Concept in Chemistry; Deb, M. B. Ed.; van Nostrand Reinhold : New York, 1981.

27. Portmann, S.; Lüthi, H. Chimia 2000, 54, 766.

28. Pettersen, E.; Goddard, T.; Huang, C.; Couch, G.; Greenblatt, D.; Meng, E.; Ferrin, T. J. Comput. Chem. 2004, 25, 1605. 